\title{
Questions in the Chemistry Class: A Comparative Study of Pedagogic Practices in Different Social Contexts
}

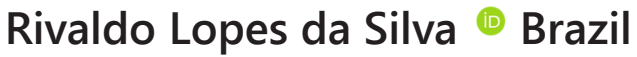 \\ Geovânia Moreira Souza • Brazil \\ Bruno Ferreira dos Santos $\odot$ Brazil
}

This article presents and discusses the findings of a research on the discourse in chemistry classes that was focused on the questions of the teacher and the students. Based on the concept of framing derived from Basil Bernstein's theory of pedagogical discourse and Hugh Mehan's initiation types, the research aimed to study the influence of social contexts on the pedagogical practice of Chemistry teachers and its manifestation on their questions in the classroom. Through the analysis, we compared the position of the teacher during the questioning episodes and the types of initiation presented in the questions asked by the teacher and his students. The research methodology was based on a case study, and the data were collected in two urban secondary schools located in different socioeconomic contexts. The results showed differences in the teacher's position in relation to the both students' answers and in relation to their questions in both schools, and also differences in the teacher's position regarding the students' questions between the schools. Based on the results of our analysis, we identified a relationship between the type of initiation and the degrees of framing of the pedagogical practice. We address these findings with the difference in the pace of the pedagogical practices between the schools and the mode of teacher's control in front of the students of the two schools. These differences generated different chains of interaction and questions with different conceptual levels.

Keywords: Chemistry teaching; classroom discourse; questionings.

\section{Introduction}

Studies on the discursive interactions between teachers and students in the classroom reveal the existence of stabilized communication patterns, mainly characterized by the teachers' questions and the students' responses, usually accompanied by an evaluation of the responses by the teacher (Mehan, 1979; Lemke, 1997). This particular communication standard, identified as IRE (Initiation-Response-Evaluation) indicates the centrality of questions in the classroom discourse. Recognizing this pattern as the dominant one in classroom discourse placed questioning as a highlighted research subject for the characterization of teaching styles and their relationship with learning in research in Education.

To Science Education, the importance of questioning is related to the fact 
that elaborating good questions is one of the key elements for scientific development (Bachelard, 1996), and this element must be present in teaching if we want school subjects to introduce students into the forms of thought and research of the different sciences. According to Aguiar Jr., Mortimer and Scott (2006), "focusing on questioning to the detriment of the responses is a way of developing an understanding of the nature of science and scientific thinking ${ }^{1 "}$ (p. 12). The use of questions in the teaching of science allows, among other things, the teacher to guide and influence students' thinking (van Zee, \& Minstrell, 1997). In addition, questions are also mechanisms capable of promoting and stimulating classroom interactions. According to the socio-cultural perspective for science education, learning occurs through the acquisition of language and the forms of thought characteristic of a given discipline, and it is mainly promoted through the discursive interactions between teachers and students (Quílez-Pardo, 2016). This perspective on learning leads us to consider dialogue - and within it, questions in particular - in the classroom as an important subject of research in scientific education.

This focus on the discursive interactions for the teaching and learning processes in science also informs us about the need of promoting more dialogical classes between teachers and students. As the IRE pattern is considered the dominant discourse in the classroom, the study on questions, both from teachers and students, can serve as an indicator of the nature of this discourse. Through questions, for example, one may be trying to promote, together with the learners, higher cognitive levels of scientific knowledge (Chin, 2013; Tobin, 1987). The engagement of students in the situations of dialogue initiated by questioning is fundamental for the establishment of dialogism, something still rare in science classes (Magalhães, Mortimer, \& Silva, 2016). However, the protagonism of the teacher in conducting the dialogue and developing the questions may also inhibit a more dialogic practice (Tytler, \& Aranda, 2015). This phenomenon has been explained, in part, by the peculiar nature of questioning in the classroom dialogue, which distances itself from the daily situations experienced by the students. In this environment, the teacher asks questions for which he already knows the answer, which can cause mistrust and discomfort among the students (Jackson, 2002).

The initiative of dialogue through students' questions depends on the creation of a favorable climate in the classroom, in which their initiatives are attended and answered, creating a friendly and encouraging atmosphere for their participation in this specific context. According to Specht, Ribeiro and Ramos (2017),

Pedagogic practices that encourage students to ask questions in class starting from their context and their reality can improve the initial explanatory models to more developed thoughts, incorporating a scientific and more complex vision, in order to increase understanding of these models and trigger questions with profiles more focused on research processes (p. 227).

However, in most of the Science classes, what can be seen is the participation of few students, whereas the vast majority remains in silence.

1 All translations of this article are ours. 
In international and Brazilian literature, several studies have been published investigating teachers and students' questions. Their authors seek to characterize and verify their relationship with the engagement in dialogue and the conceptual learning of students in a variety of teaching situations and didactic strategies, as in the school laboratory or through problem-based learning (Specht, Ribeiro, \& Ramos, 2017; Andrade, \& Mozzer, 2016; Silva, 2015; Kawalkar, \& Vijapurkar, 2013. Erdogan, \& Campbell, 2008; Schein, \& Coelho, 2006; Chin, 2006; Bleicher, Tobin, \& McRobbie, 2003). Likewise, research can be found addressing the presence of questions in textbooks and school manuals (Torres, Almeida, \& Vasconcelos, 2015).

In a previously carried out research, we observed a remarkable difference in the communication between teachers and students in chemistry classes: the same teacher who gave classes in schools whose students belonged to different socioeconomic contexts managed to obtain a much greater participation in the dialogue in the classroom with the students coming from economically more favored means than from those belonging to the popular classes (Souza, 2015). As an initial hypothesis for the explanation of this difference, we assume the possibility of the influence of the social context on the pedagogic practice of the teacher in question.

Using the data obtained in this previous survey, we attempted to analyze the questions of this teacher and his students in order to understand, in a comparative study, the nature of these questions and whether the developments in the dialogue would be favoring or limiting the participation of the students in the discursive interactions. Starting from this initial goal, this article presents and discusses the results of the analysis of the pedagogic practice of a Chemistry teacher, guided by the following research questions:

How are the types of questions from the teacher and the students distributed in the two school contexts?

Is there variation in the control of the communication by the teacher in the two contexts during questioning?

Is there an observable relationship between the teacher's control of communication and the cognitive level of the questions?

\section{Theoretical framework}

The relationship between education and society is addressed by the Sociology of Education, which has as one of its main objectives to investigate and understand how cultural goods are distributed, via education, among the different social segments. This branch of Sociology is also interested in understanding how this distribution contributes to the reproduction of educational and social inequalities within a society. In the study of these phenomena, Basil Bernstein's theory of pedagogic discourse stands out since it relates the microcontexts of education, such as the classroom space, with broader social contexts. Through the concepts of classification and framing, Bernstein proposes to verify how the sociological categories of power and control, respectively, act on the 
pedagogic practices developed within the schools. For this author, the distribution of power and control originates itself from the social division of labor and influences, thereby, the relations between social classes. According to his theory, power and control are translated into principles of communication in the pedagogic relationship. The pedagogic discourse, in turn, is the institutionalized device that distributes awareness, message and voice, under the different orientations assumed by power and control within a given society.

Classification, according to Bernstein, reflects the isolation among categories: subjects, discourses and spaces. The greater the isolation, the stronger the degree of classification among these categories, which contributes to the subjects' recognition of the different contexts in which they are located. Framing reflects the control that a subject who occupies a higher position in a hierarchical relationship is able to establish in the communication between them and the other subjects present in a particular social relationship and in a particular context. In pedagogic practice, the greater the control over the elements of discourse (selection, sequence, pacing and evaluation criteria), the stronger the framing degree; when subjects who occupy lower positions in a hierarchical relationship assume some control over the elements of discourse, there is a weakening of the framing degree. Bernstein argues that

The control exercised by the teacher determines who can speak, which voice can be heard, what can be said and, thus, which identity remains selectively legitimized. The teacher's control regulates the extent to which the skills and communicative practices of the families and the community can be effective in the classroom or regulates, better, which communication skills and which practices may result effective (1988, p. 135).

Framing relates to the realization rules and enables the subjects, when in possession of these rules, to produce the legitimate text for each context in which they are located and interpellated (Bernstein, 2001).

The combination of different degrees of classification and framing gives rise to different modalities of pedagogic practices, from the more "traditional" to the more "progressive", and configures different types of pedagogic codes. In order to succeed, the learners must be able to acquire the particular orientation of the code associated with a particular pedagogic practice. This means that success implies the acquisition, by the learners, of both the recognition rules as well as the realization rules, so that they can produce the text that is adequate or legitimate for the context in which they are located, as can be the case of a Chemistry class. Text, here, refers to any production, material or otherwise, conceived by the subjects. According to Morais (2002),

The understanding of differential achievement in science requires an analysis of specific pedagogic discourses as a set of rules that regulate the transmission/acquisition of scientific knowledge. Pedagogic discourse refers not only to the scientific contents and competences to be transmitted, but also to their transmission and evaluation - that is, it refers to the what that is transmitted, how it is transmitted, and also which student 
realisations are considered legitimate (p. 560).

According to Bernstein's (2001) theory, the principles of control establish the social relations that, in turn, define the principles of communication, characterized by framing. The communicative context will depend not only on framing, but also on classification, since the pedagogic code is defined by both. In addition, Bernstein differentiates two modalities in pedagogic discourse: a regulative discourse and an instructional discourse. The first one deals with questions of order, of behavior and identity, and is characterized by hierarchical rules, which define the subjects' roles within a social relation. The second is given by the discursive rules and transmits the contents and competences in pedagogic practice. According to this sociologist, instructional discourse is subsumed in regulative discourse, which is the dominant discourse.

Bernstein also distinguishes different languages for theory and research, an internal language, that describes the relationships within the theory, and an external one, that allows to describe what is outside the theory (i.e., the empirical world). Therefore, an analysis supported by Bernstein necessitates the construction of this external language that will allow to use his theory with the empirical referential elements (Moore, \& Muller, 2003). The external language used in this work was developed by Morais and Neves (2001) and adapted for our research questions. According to these authors, such language is mainly derived from the internal language of Bernstein's theory, it is able to establish a dialectic relationship between the theory and the empirical referent.

This sociological approach to research in Science Education has as focus the social relations that constitute pedagogic activity. Such relationships involve the subjects, discourses, and the agencies and spaces. In the specific case of this research, we aimed to investigate the teacher/student relationships, by means of the hierarchical rules, that can be analyzed considering both classification and framing. As we are particularly interested in questions, that is, in communication, our investigation is oriented by the study of the principles of communication characterized by framing. these rules can be explicit (assuming a strong framing degree) and implicit (assuming a weak framing degree). When the rules are explicit, the power relations between transmitter and acquirers are very clear; when they are implicit, it becomes more difficult to distinguish the transmitter from the acquirer. Hierarchical rules, therefore, relate exclusively to the relationships between subjects (Bernstein, 2001).

The study of the questions, in turn, has been based on different typologies (Torres, Almeida, \& Vasconcelos, 2015). The key criterion used to distinguish between question types is the level of demand or conceptual and/or cognitive exigence of the questions. One of the typologies employed for the analysis of questions in the classroom is the classification of the elicitation types proposed by Hugh Mehan (1979), a system that includes four types of questions and was based on an ethnographic study developed by this author. According to Mehan, these types are:

1. Choice elicitation: "choice elicitation calls upon the respondent to agree or disagree with affirmation statement provided by the questioner" (Mehan 1979, p. 44). 
To Mortimer et al. (2007, p. 66), "besides the choice between yes or no, we also have the choice between two different possibilities". In this type of elicitation, we find questions like: 'It's fluorine, isn't it?', 'But are electrons not nonbonding?', 'Then will the name of the base be added?

2. Product elicitation: "Product elicitation asks respondents to provide a factual response such as a name, a place, a date, a color" (Mehan 1979, p. 44). According to Mortimer et al. (2007, p. 67),

This type of elicitation usually takes the form of a "what" or "which" question, which elicits a noun or an adjective denoting an agent, an event, a nominative process, a property, and so on.

For this category, we find questions like: 'What is a phosgene?', 'How many geometries are there?', 'Teacher, what is sawdust?'.

3. Process elicitation: "process elicitation asks for respondents' opinion or interpretations" (Mehan, 1979, p. 45). According to Mortimer et al. (2007, p. 66), this kind of elicitation is formed by " 'why', 'how' or 'what happens' questions that elicit a specific process that should normally be described or explained by a complete sentence". The elicitations found for this category can be questions like: 'why is there magnesium sulfate left?', 'How so in balance?'.

4. Metaprocess elicitation:

[...] a fourth kind of elicitation asks students to be reflective about the process of making connections between elicitations and responses. These elicitations are called metaprocess elicitations because they ask students to formulate the grounds of their reasoning (Mehan, 1979, p. 46, quoted in Mortimer et al., 2007, p. 67).

For this category we find questions like: 'What if you stay in a place without oxygen?', 'How can we justify this?.'

By means of the approximation of a theoretical framework from the Sociology of Education and another coming from Interactional Ethnography, we aimed to investigate the pedagogic practice in the teaching of Chemistry, relating the intersection between the cultural patterns of participation in classroom discourse and the scientific disciplinary context. This intersection has been absent in the existing literature, as observed by Lee (2005). This article aims to analyze the types of questions of the teacher and his students in both classroom settings investigated, contrast their results and analyze the teacher's control in the episodes of the questions, through the framing degrees. Our purpose is to establish correlations between the results obtained through the different analyses and by means of them identify the manifestation of the influence of the social context on the pedagogic practice in chemistry. With this research we hope to contribute to the understanding of the learners' participation in the classroom discourse of this discipline, considering as the main variable the students' social context. 


\section{Methodological path}

This research is defined as an instrumental case study. Such perspective of case study "allows both inductive and deductive procedures, and is oriented both to grasp the subjective and objective aspects of social life" (Neiman, \& Quaranta, 2007, p. 222). Based on Robert Yin's (2005) definitions of case study, Neiman and Quaranta argue that:

The sample is intentional according to the thematic and conceptual interests, and the cases can be selected according to different criteria, for example, from certain conditions that transform the case into a single phenomenon or constitute it in a paradigmatic expression of a social problem. The case is defined as a system delimited in time and space of actors, relationships and social institutions where one seeks to account for the particularity of its particularity within the framework of its complexity (Neiman, \& Quaranta, 2007, p. 219-220).

The methods and techniques for this study's data production were: observation of lessons from a chemistry teacher in two schools, one private and one public, records of the classes through audio recorder and field diary, and transcription of the audios. The records in the field diary were used to contextualize the transcribed data. The classes were observed during one school period (approximately two months) in each school unit. A socioeconomic questionnaire was applied to both classes in order to obtain the students' profile to characterize them regarding the social context to which they belonged. The results of this survey confirmed that the students pertained to different socioeconomic strata when we contrasted the data on education and occupation of their parents (Souza, 2015). It has to be noted that our entry in the field only occurred after approval of the research project that gave rise to this investigation by the Ethics Committee of our university.

The schools that served as the research setting are located in different urban regions. The public school is located in a peripheral district and attends, principally, students from the community in which it is located. The private school is located in a central region, and its students come from various neighborhoods of the city. The class observed in the public school had 44 students, while the one in the private school had only 32. The age of the students was equivalent between the observed groups. The chemistry teacher was young, with only five years teaching experience at the time of the observations. He holds a BA and a Master's degree in chemistry from the same institution, a public university in the inland of Bahia. Two semi-structured interviews were carried out after the observations at each school, aiming to know the didactic and pedagogic orientations chosen by the teacher with respect to the different groups of students and schools where he was teaching at the time of our observations. The data of these interviews were used in a complementary manner for the interpretation of the results of the analyses of the pedagogic practices.

The classes were taught in classes of the first year of high school and corresponded to the contents of atomic structure, chemical bonds and reactions. The observations 
totaled 48 classes, 24 in each school. The transcripts of the class audios, together with their contextualization through the records in the field diary, were followed by their fragmentation in episodes. Altet (2000) defines an episode as a particular unit of discourse. "An episode begins with an expression that triggers a verbal exchange on a particular subject and ends when the discussion on the subject ends" (Altet, 2000, p. 66), and may consist of one or more interactions on the subject or occasions. The episode consists, thus, of several communications with a beginning, a middle and a conclusion.

For the analysis of the questions, we selected all the episodes in which we verified the presence of questions from the teacher and/or the students. In the case of the teacher's questions, we used the interactions that produced a response by some students as choice criterion. Thus, we eliminated the rhetorical questions and those that were not answered. The selected questions were quantified and analyzed according to Mehan's elicitations typology and also according to two instruments called indicators, related to the hierarchical rules in the teacher-student relationship, to determine the framing degree. One of the indicators used in this analysis was adapted from the ESSA ${ }^{2}$ group and the other was designed for this research according to our objectives. These indicators will be introduced in the next section of this article.

\section{Results and discussion}

In the data presented below, we denominate the public school as PU and the private school as PR. Figure 1 shows the total amount of questions - both from teacher and students -in the episodes of the two classes that were observed.

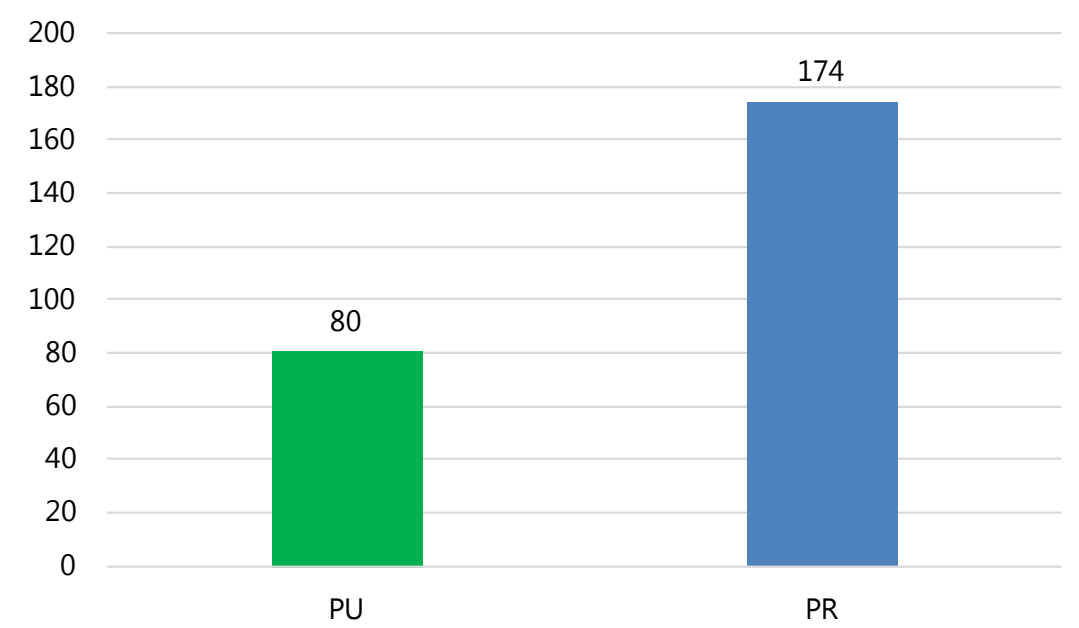

Figure 1. Total amount of questions observed in the public and private school classes

Source: Own elaboration

Figure 1 shows that, for the same quantity of classes, a little more than the double of the number of questions occurred in the private school versus the public school. This

2 ESSA Group: Estudos Sociológicos de Sala de Aula, linked to the Universidade de Lisboa and coordinated by the researchers Ana Maria Morais and Isabel Pestana Neves. 
trend remains when we separate the teacher's and the students questions in the two schools, as illustrated by Figure 2, although the amount of questions by the students of the public school is less than half than the one found in the private school. These results also confirm the teacher's role in this kind of dialogue, which is higher in the public school under assessment, since in the latter the number of his questions represents approximately three times the one of the students (in the private school, this proportion is approximately twice). This could indicate that the students of the private school feel more comfortable asking questions than those of the public school. These numbers also reflect a higher amount of teacher/student interactions, via questions, in the private school.

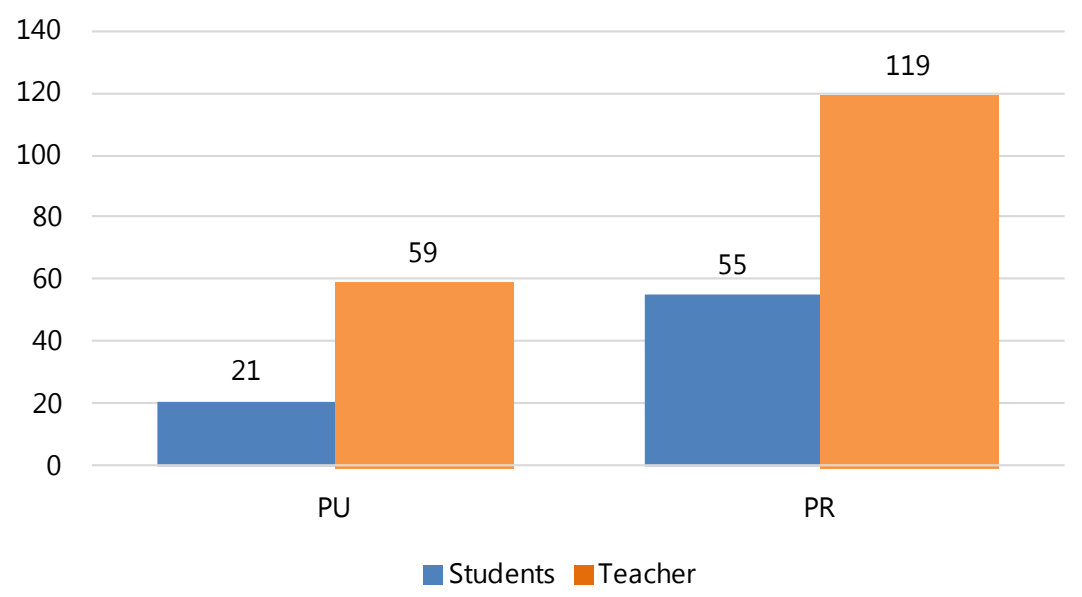

Figure 2. Total amount of students and teacher questions by school

Source: Own elaboration

This quantitative difference between the questions in the two schools can be understood considering the time factor: the teacher has only two classes per week (50 minutes for each class) in the public school, while in the private school his hourly workload is doubled. This imposes a more intense pacing on the pedagogic practice in the public school

With a very intense pacing, time becomes scarce and this regulates the examples, the illustrations and the reports that facilitate acquisition; it determines which questions can be demanded and in what quantity; [...] In addition, an intense pacing tends to reduce the oral interventions of the student and favor, instead, the discourse of the teacher, and this is something that the students consider preferable since the time is scarce for the official pedagogic message. Thus, the proper deep structure of pedagogic communication remains affected (Bernstein, 1988, p. 138).

We suggest that this inequality in the available time for pedagogic communication in the classroom between the two schools is one of the main factors that produces the differences, not only in the absolute amount of questions posed by the teacher and the 
students, but also for the different proportion between the questions of the teacher and his students in each observed group.

The questions were also classified according to the typology proposed by Mehan. As for the teacher's questions in both schools, the results of the analysis of the types of elicitations are shown in Figures 3 and 4.

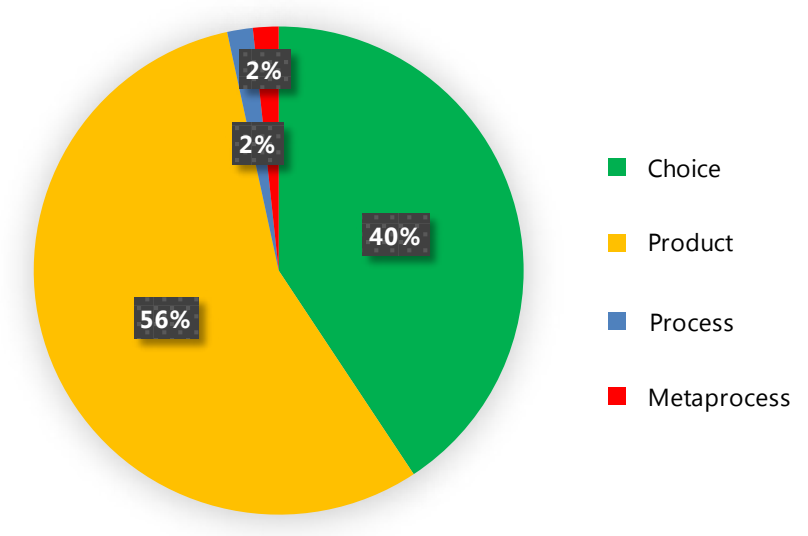

Figure 3. Types of elicitation by the teacher/Public school

Source: Own elaboration

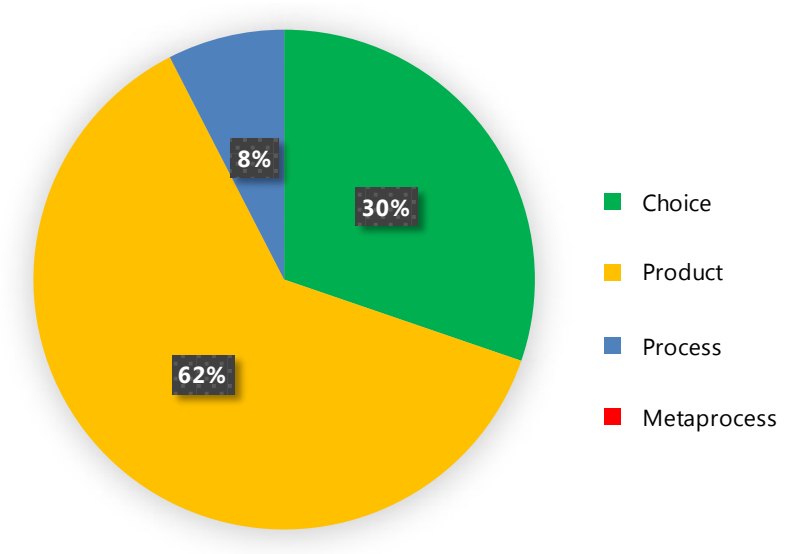

Figure 4. Types of elicitation by the teacher/Private school

Source: Own elaboration

The graphs shown in Figure 3 and 4 show that product elicitation predominates in both classes (62\% and 56\%, respectively, in the private and public school). This means a dialogue in the classroom in which questioning consists primarily of closed questions, which explore the learning of concept names and the results of numerical calculations, often in the form of filling in gaps in the teacher's discourse. Choice elicitations follow, with a lower frequency in the private school compared to the public school $(30 \%$ and $40 \%$ ). This slight difference makes room for process elicitations in the private school, reaching $8 \%$ of the teacher's questions against only $2 \%$ in the public school. However, his questions in both classes are mainly composed of elicitation type questions of lower 
conceptual demand, with few examples of questions that ask for the opinion or the interpretation of the students. This is illustrated by fragments of episodes of the two observed classes shown in Figure 5.

\begin{tabular}{|c|c|}
\hline PU: Lesson on chemical reactions & PR: Lesson on molecular geometry \\
\hline $\begin{array}{l}\text { Teacher: Twelve, what is the relation of twelve } \\
\text { to six in the previous experiment? (Product } \\
\text { elicitation) } \\
\text { Student: It's twice as much! } \\
\text { Teacher: It's twice as much... it used twice as } \\
\text { much nitrogen gas and what did it use from } \\
\text { eighteen to thirty-six? What is the relationship? } \\
\text { (Product Initiation) } \\
\text { Student: The double. } \\
\text { Teacher: Right, it used twice as much. }\end{array}$ & $\begin{array}{l}\text { Teacher: No [ ]... when you think of four } \\
\text { electron clouds around the central atom, you } \\
\text { don't think about a triangle, you will think of an } \\
\text { arrangement, will think of an arrangement of } \\
\text { what? What arrangement will I have? (Product } \\
\text { elicitation ) } \\
\text { Student: It's... } \\
\text { Teacher: What arrangement? } \\
\text { Student: A diamond. } \\
\text { Teacher: What will it be? } \\
\text { Student: Like a diamond. } \\
\text { Teacher: Like a diamond. }\end{array}$ \\
\hline
\end{tabular}

Figure 5. Fragments of episodes with teacher questions in PU and PR

Source: Own elaboration

For the analysis of the control of the communication by the teacher and its relation with the types of elicitation of the questions, we elaborated an indicator that shows the positioning of the teacher in front of the answers given by the students. This indicator allows to verify how such positioning encourages the development of a longer dialogue, or with more ramifications than that observed in standard IRE. Figure 6 shows the proposed indicator and the respective degrees of framing assigned to different teaching situations.

\begin{tabular}{|c|c|c|c|c|}
\hline Indicator & $\mathbf{E}^{++}$ & $E^{+}$ & E- & E - \\
\hline $\begin{array}{l}\text { Teacher's } \\
\text { question }\end{array}$ & $\begin{array}{l}\text { The teacher } \\
\text { always evaluates } \\
\text { the students } \\
\text { response by } \\
\text { confirming or } \\
\text { rejecting it. }\end{array}$ & $\begin{array}{l}\text { When listening } \\
\text { to the student's } \\
\text { response, the } \\
\text { teacher asks new } \\
\text { questions and/ } \\
\text { or develops } \\
\text { considerations to, } \\
\text { together with the } \\
\text { student, confirm or } \\
\text { reject their initial } \\
\text { response. }\end{array}$ & $\begin{array}{l}\text { The teacher } \\
\text { listens to the } \\
\text { response and } \\
\text { encourages } \\
\text { other students } \\
\text { to speak out to, } \\
\text { then, evaluate, } \\
\text { confirming or } \\
\text { rejecting the } \\
\text { answers. }\end{array}$ & $\begin{array}{l}\text { After encouraging } \\
\text { the other students } \\
\text { to express } \\
\text { themselves, the } \\
\text { teacher listens to } \\
\text { their answers and } \\
\text { causes a discussion } \\
\text { among them so } \\
\text { that they can reach } \\
\text { a consensus on the } \\
\text { correct answer. }\end{array}$ \\
\hline
\end{tabular}

Figure 6. Description of the indicator used in the evaluation of the framing degree of the teacher's questions 
The results of the analysis of the episodes selected through this indicator for each school are shown in Figures 7 and 8.

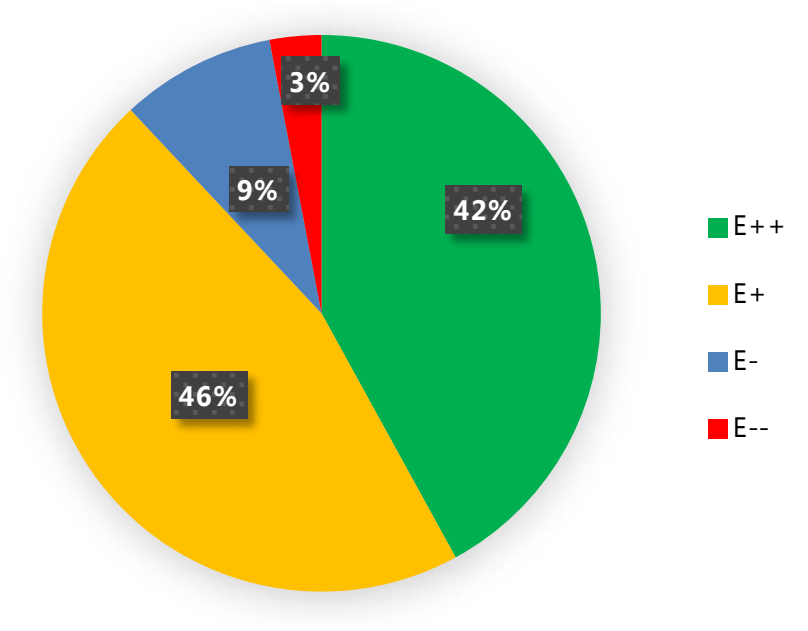

Figure 7. Framing degrees for the teacher's questions in the public school

Source: Own elaboration

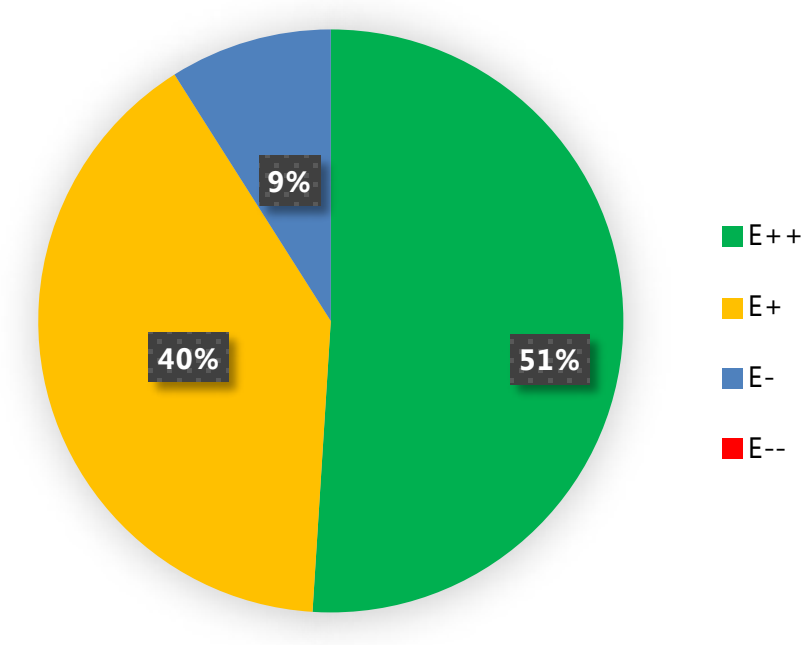

Figure 8. Framing degrees for the teacher's questions in the private school

Source: Own elaboration

The results of this analysis revealed a greater tendency to a very strong degree of framing $\left(\mathrm{E}^{++)}\right.$from the teacher in the private school (51\%) compared to the one observed in the public school $(42 \%)$. The degree of very weak framing $\left(\mathrm{E}^{-}\right)$, for example, was only observed in the latter setting. These results, in principle, would reveal a pedagogic practice slightly more favorable to interactions and dialogue beyond the IRE standard in the public school than in the private school. However, as most of the elicitations in both schools are product elicitations, the observed difference in the framing degree might indicate an increased difficulty of the public school students in learning the names of 
concepts, or even executing simple numerical calculations, as can be seen in the episode fragments shown in Figure 9.

\begin{tabular}{|l|l|}
\hline PU: Lesson on chemical laws & PR: Lesson on Molecular Geometry \\
\hline Teacher: What is an atom...? (Product & Teacher: That is my question... Do I have many \\
elicitation) & electron clouds around the central atom? Around \\
Student: Molecules. & the central atom... How many do I have? (Product \\
Teacher: Molecules, what more? & Student: Three. \\
Student: Small particles. & Teacher: Three... and these three electron clouds \\
Teacher: Small particles, perfect. & are binders? (Choice Elicitation) \\
$\left.\mathbf{( E}^{+}\right)$ & Student: two of them are and one isn't. \\
\hline
\end{tabular}

Figure 9. Fragments of episodes of the teacher's questions in PU and PR

Source: Own elaboration

In the next step of our analysis, we associate the types of elicitation of the teacher's questions with their respective framing degrees. The results of this analysis appear in Figures 10 and 11.

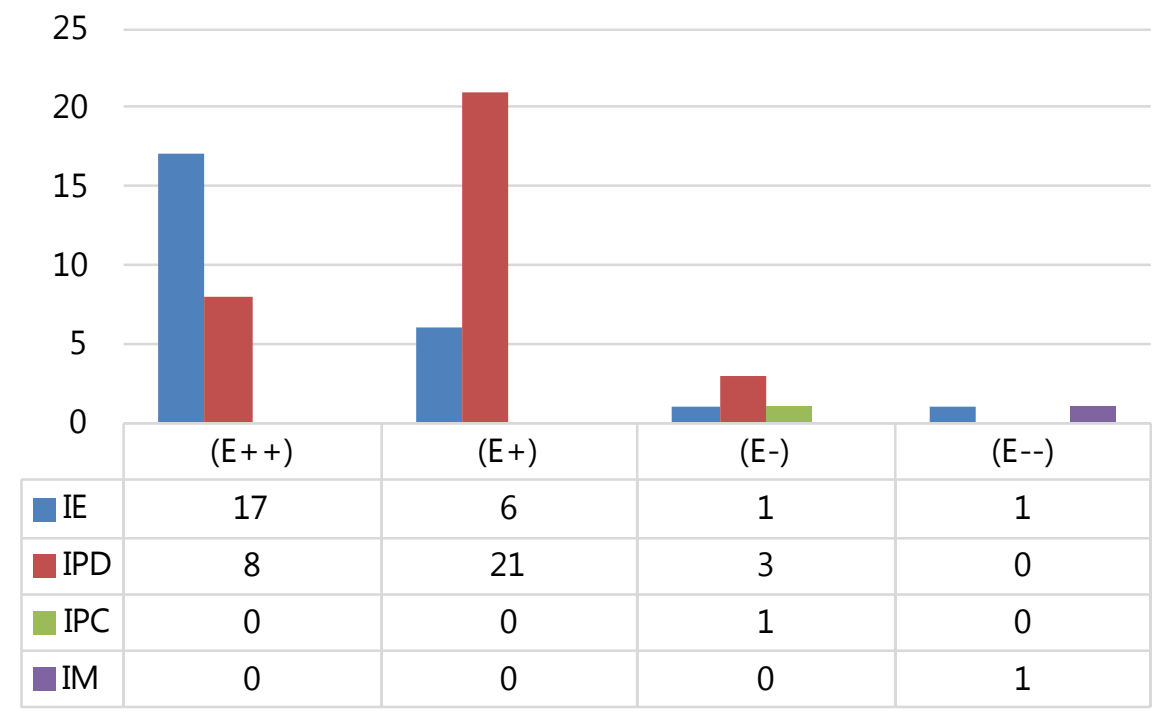

Figure 10. Relationship between the framing degree and the elicitation types of the teacher in the public school

Source: Own elaboration 


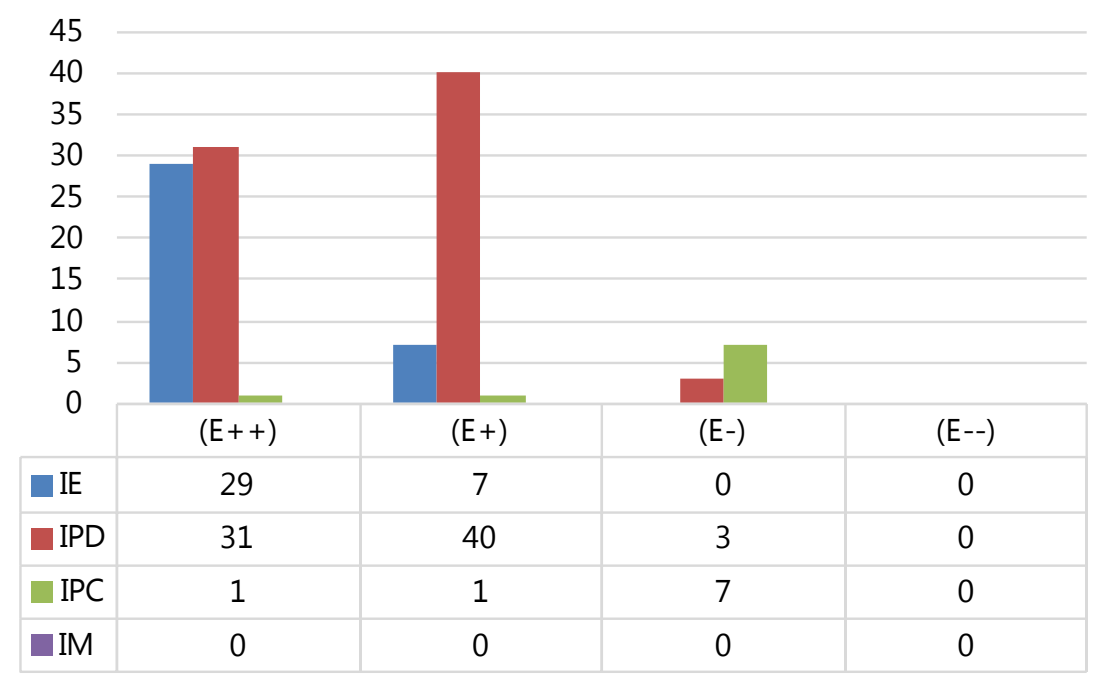

Figure 11. Relationship between the framing degree and the elicitation types of the teacher in the private school

\section{Source: Own elaboration}

The higher association of product elicitations with a strong framing degree in the public school is evidenced by Figures 10 and 11, since for the private school this association was just over half for this type of elicitation, while in the public school it accounted for almost three quarters of the total amount. The results of this analysis also showed that the few episodes observed with process and metaprocess elicitations in both groups promoted a weakening of the framing degree in the teaching practice. This means that questions with greater conceptual demand led, in most cases, to a longer dialogue, with more teacher-student interactions. This can be seen in the fragments of episodes of the two schools shown in Figure 12. As the episodes of elicitations of these two types were slightly more frequent in the private school, the association between elicitation types and weaker framing degrees was more visible in the questions of this school. 


\begin{tabular}{|c|c|}
\hline PU: Lesson on chemical reactions & PR: Lesson on molecular geometry \\
\hline $\begin{array}{l}\text { Teacher: It stays normal, ok! Does it stay? } \\
\text { normal? Do you think it goes downwards, } \\
\text { why do you think it goes downwards?... } \\
\text { Why do you think it goes downwards? } \\
\text { (process elicitation) } \\
\text { Student: I don't think it goes downwards, it } \\
\text { stays normal (laughs) } \\
\text { Teacher: Stays normal? } \\
\text { Student: Erm, I think it stays in balance } \\
\text { Teacher: It stays in balance!... } \\
\text { (E') }\end{array}$ & $\begin{array}{l}\text { Teacher: A Tetrahedron is a polyhedron of [...] a } \\
\text { regular polyhedron where you will get all interior } \\
\text { angles equal, all facial areas equal, why is that LM? } \\
\text { (process elicitation) } \\
\text { Student: Will it always be like that? } \\
\text { Teacher: Why are all the electron clouds of the same } \\
\text { nature: they are all what? Identical... alright? Okay, } \\
\text { next molecule, ammonia } \mathrm{NH}_{3}[\ldots . . .] \text { to determine the } \\
\text { geometry and arrangement of ammonia, the first } \\
\text { step is? } \\
\text { Students: The electrons. } \\
\text { Teacher: Calculate the valence electrons... nitrogen? } \\
\text { Nitrogen? Five plus one hydrogen, three times, one, } \\
\text { three times... three plus five?... eight. And now what } \\
\text { do I do? } \\
\text { Students: Divide by two. } \\
\text { Teacher: Eight divided by two, I need to have four } \\
\text { pairs of electrons. } \\
\text { (E) }\end{array}$ \\
\hline
\end{tabular}

Figure 12. Fragments of episodes of the teacher's questions in PU and PR

Source: Own elaboration

In Figure 13, we show the frequency of the elicitation types for the questions of the public school students. Metaprocess elicitations were not observed in the questions of the students from this school.

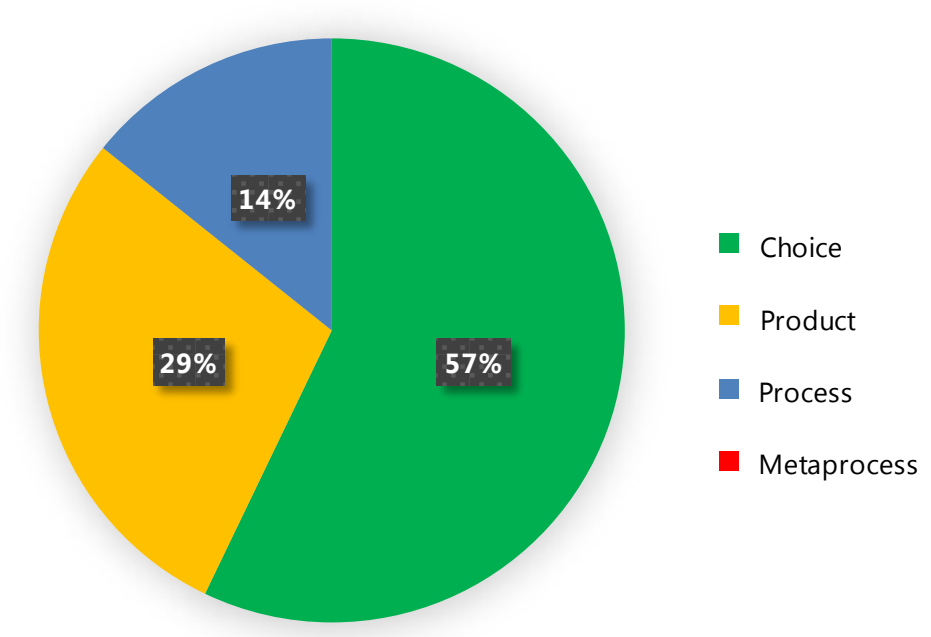

Figure 13. Types of elicitation of the public school students

Source: Own elaboration 
Figure 14 shows the results of this analysis for the private school, in which all the initiation types were found.

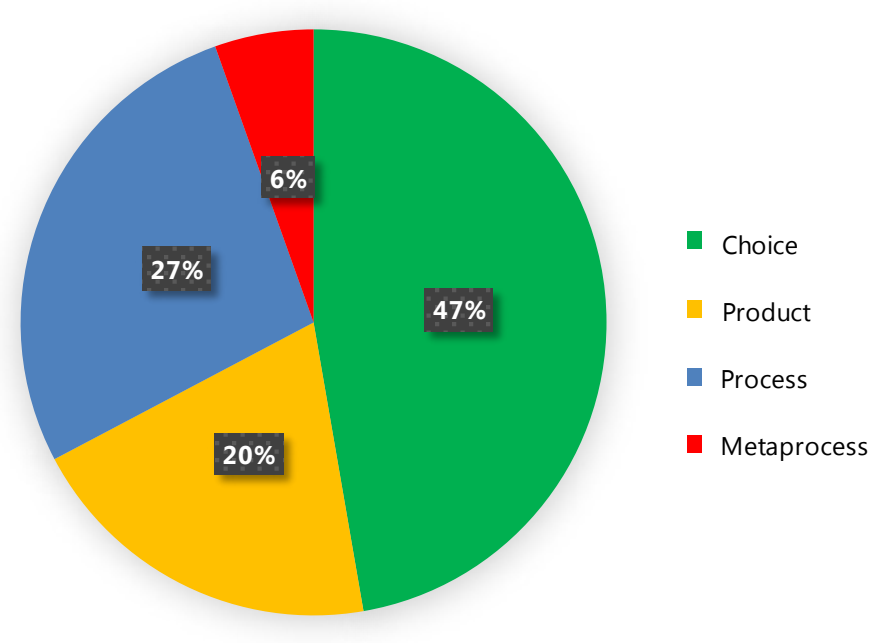

Figure 14. Types of elicitation of the private school students

Source: Own elaboration

Figure 15 provides examples of episodes involving choice (the highest rate) and process elicitations of the students at both schools. The absence or low frequency of metaprocess elicitations coincides with Mehan's observation (1979) that this type of elicitation is the rarest in the interactions between teachers and students, when compared with other types of elicitation. However, it has to be noted that a lower frequency of higher cognitive demand elicitations (process and metaprocess) occurs among the public school students compared to the one observed in the private school (14\% and $33 \%$, respectively). If we consider that the latter asked more questions during the lessons (see Figure 3), then the interactions between them and the teacher have more episodes involving open questions that ask for explanations and opinions, while the vast majority of the public school students' questions ( $86 \%$ of the total) are simple and closed questions. According to Aguiar Jr., Mendonca and Silva (2007),

The difficulties of the students to formulate good questions may be linked to both cognitive factors - difficulties in identifying conflicting information or recognizing concepts that are needed to continue the required reasoning - and social factors - fear of looking foolish to colleagues and teacher, difficulties to take a speech turn or change the topic under discussion in a lesson, among others (p. 3). 


\begin{tabular}{|c|c|}
\hline \multicolumn{2}{|l|}{ Choice elicitation } \\
\hline PU: Lesson on inorganic functions & PR: Lesson on molecular geometry \\
\hline $\begin{array}{l}\text { Teacher: The termination changes, the prefix } \\
\text { is sulf. It is not sulfu, the prefix is sulf and the } \\
\text { termination ato. } U \text { is not a prefix, it is a radical } \\
\text { of the word. } \\
\text { Student: Then, will it add the name of the base? } \\
\text { Teacher: The base doesn't enter. }\end{array}$ & $\begin{array}{l}\text { Student: Oh, LM, but aren't electrons } \\
\text { nonbonding? } \\
\text { Teacher: Yes. } \\
\text { Student: So, you kind of excluded them. }\end{array}$ \\
\hline \multicolumn{2}{|l|}{ Process Initiation } \\
\hline PU: Lesson on composition of matter & PR: Lesson on chemical reactions \\
\hline $\begin{array}{l}\text { Student: What is the name? And how come? } \\
\text { Teacher: Leucippus and Democritus, Leucippus } \\
\text { is one, and Democritus is another. They } \\
\text { raised this hypothesis before Christ, only } \\
\text { as a philosophical thought, nothing proven } \\
\text { experimentally. How did they came to the idea? } \\
\text { Working with bricks, accidentally a brick fell on } \\
\text { the ground. When the brick fell on the ground, } \\
\text { it split into two parts. Then, one of them took } \\
\text { a part of it and split it into two more, took this } \\
\text { other broken part and split it into two more, } \\
\text { they kept breaking up the matter until they } \\
\text { couldn't fragment it more and came to a very } \\
\text { small part that they could not split. Then they } \\
\text { said: all matter is made up of this indivisible part } \\
\text { that I will call atom... }\end{array}$ & $\begin{array}{l}\text { Student: what do you mean, donated? } \\
\text { Teacher: what do you mean, donated? OH, } \\
\text { now I only have } \mathrm{O} \text { in all the chemical species } \\
\mathrm{C}_{6} \mathrm{H}_{5} \mathrm{OH} \mathrm{C}_{6} \mathrm{H}_{5} \mathrm{O}^{-} \text {. Because it lost the proton, lost } \\
\text { the species } \mathrm{H} \text { to form this } \mathrm{O}^{-} \text {. And then what } \\
\text { happens? The others, did you understand the } \\
\text { others, } \mathrm{M} \text { ? Right, what's the difference of these } \\
\text { compounds with the one above? This one is an } \\
\text { anion, this other one is also an anion, ((pointing } \\
\text { to the species represented on the whiteboard)) } \\
\text { here he had to gain one, here he had to gain two. } \\
\text { Well and because it lost a chemical species, it lost } \\
\text { this proton here, } \mathrm{H}^{+} \text {. Now look at this here, } \mathrm{O}^{-} \text {. } \\
\text { And look at this } \mathrm{OH} \text { here, what does it mean? }\end{array}$ \\
\hline
\end{tabular}

Figure 15. Fragments of episodes of the questions of the PU and PR students

Source: Own elaboration

We also analyzed the framing degrees of the pedagogic practice for the situations of students' questions. Therefore, we used an indicator through which we sought to demonstrate communication control in teacher-student exchanges in episodes where the students ask questions. Figure 16 shows the description of the indicator and its respective framing degrees, ranging from very strong $\left(\mathrm{E}^{++}\right)$to very weak $\left(\mathrm{E}^{--}\right)$. 


\begin{tabular}{|c|c|c|c|c|}
\hline Indicator & $\mathrm{E}^{++}$ & $\mathrm{E}^{+}$ & $\mathrm{E}^{-}$ & $\mathrm{E}^{--}$ \\
\hline $\begin{array}{l}\text { Questions of the } \\
\text { students }\end{array}$ & $\begin{array}{l}\text { The teacher } \\
\text { ignores the } \\
\text { questions. }\end{array}$ & $\begin{array}{l}\text { The teacher } \\
\text { responds } \\
\text { directly to the } \\
\text { students. }\end{array}$ & $\begin{array}{l}\text { The teacher responds } \\
\text { to the students, } \\
\text { formulating } \\
\text { other questions } \\
\text { and providing } \\
\text { some additional } \\
\text { information. }\end{array}$ & $\begin{array}{l}\text { The teacher } \\
\text { responds to } \\
\text { the students, } \\
\text { promoting a } \\
\text { discussion among } \\
\text { several students. }\end{array}$ \\
\hline
\end{tabular}

Figure 16. Description of the indicator used in the evaluation of the framing degree of the students' questions

In the public school's pedagogic practice only two framing degrees appeared, classified as strong $\left(\mathrm{E}^{+}\right)$and weak $\left(\mathrm{E}^{-}\right)$. Figure 17 illustrates the frequency distribution of these degrees in the analyzed episodes. The strong framing degree was predominant, i.e. the teacher responded directly to the students for most of their questions. The predominance of this framing degree means that few opportunities are created, in the case of student initiatives, to expand or extend the dialogue to other forms, beyond simple question-answer threads.

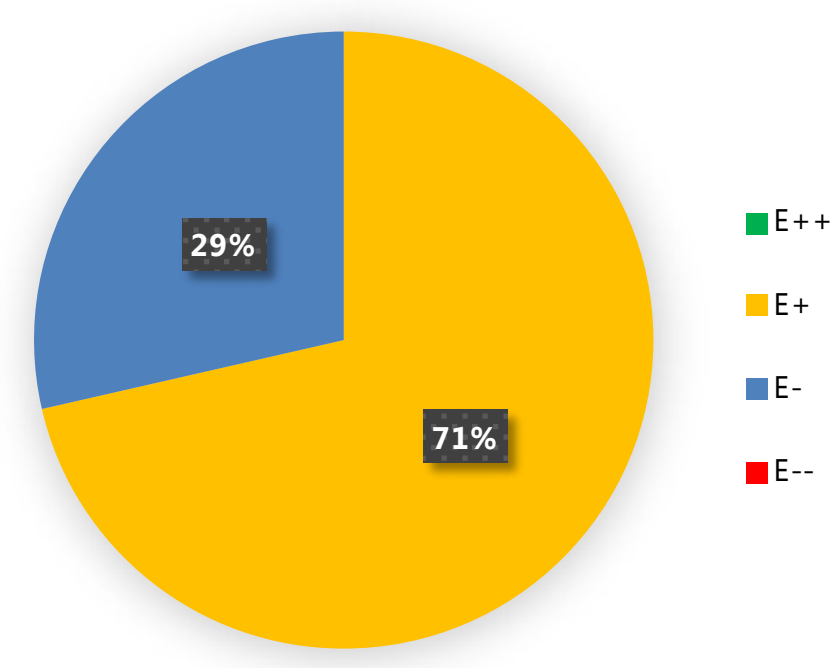

Figure 17. Framing degrees for the questions of the Public School students

Source: Own elaboration

The analysis of the episodes of the private school student's questions reveals a slightly different setting, in which all framing degrees are observed, as depicted in Figure 18. Most of them are low degree $\left(\mathrm{E}^{-}\right)$, accompanied by strong degree $\left(\mathrm{E}^{+}\right)$, while the remaining are approximately one fifth of the episodes. In this case, when answering the students' questions, the teacher usually used to provide more information besides what was requested, or, even, extended the dialogue with new questions, generating new chains of interaction between the students and himself. In considering the predominant framing degrees in both schools, it is concluded that the teacher's positioning was different between them, since he answered more directly to the public school students 
than to those of the private school. This is illustrated by the fragments of episodes shown in Figure 19.

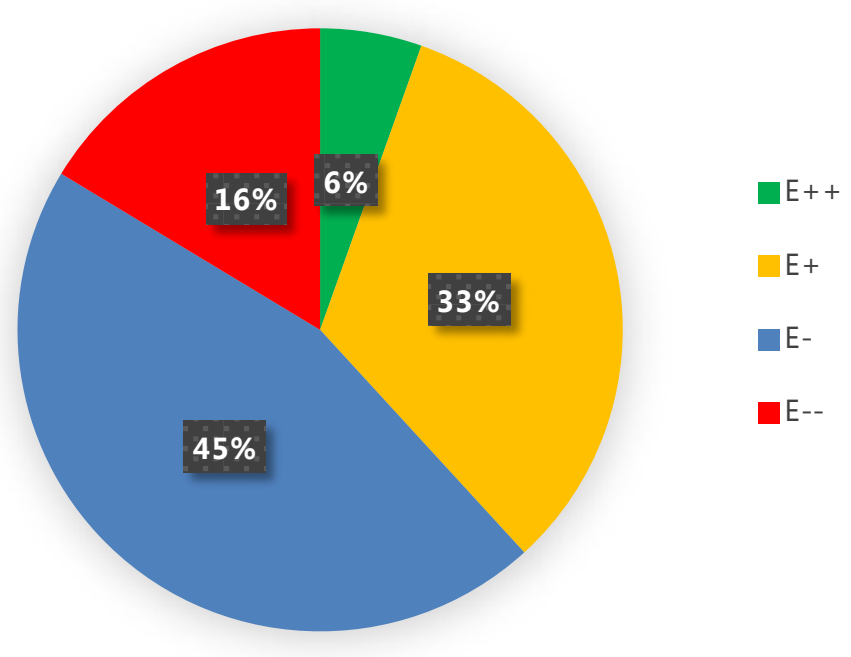

Figure 18. Framing Degrees for the questions of the Private School students

\begin{tabular}{|c|c|}
\hline PU: Lesson on chemical reactions & PR: Lesson on Molecular Geometry \\
\hline $\begin{array}{l}\text { Student: Teacher, what is wood dust? } \\
\text { (Product elicitation) } \\
\text { Teacher: Sawdust. } \\
\left(\mathbf{E}^{+}\right)\end{array}$ & $\begin{array}{l}\text { Student: What is the polarity? (Product elicitation) } \\
\text { Teacher: Nice, what is the polarity of this one? } \\
\text { Students: This one?/it is nonpolar/oh teacher do we } \\
\text { add the vectors? (Choice elicitation) } \\
\text { Teacher: All the vectors. } \\
\text { Student: Then it is nonpolar. } \\
\text { Teacher: Then it is nonpolar? Let's see: Fluorine with } \\
\text { bromine, which is more electronegative? Fluorine... } \\
\text { the electron density is also pointing to where?... to } \\
\text { the nonbinding electrons, ok? Well, then you think of } \\
\text { vectors being canceled so you can/ } \\
\text { (E) }\end{array}$ \\
\hline
\end{tabular}

Figure 19. Fragments of episodes for framing degrees in PU and PR

Source: Own elaboration

According to Morais (2002), a weaker framing regarding the hierarchical rules creates a context in which students feel more at ease to question, discuss and share their ideas. This, in turn, allows the teacher to strengthen framing in terms of the evaluation criteria, which means providing students the rules by which they will be able to produce the legitimate text in the school context. According to the same author, the control mode exercised by the teacher using stronger framing for hierarchical rules is imperative/ 
positional, with a greater separation between the role of the teacher and the students. On the other hand, with a weaker framing, the teacher uses personal control, which contributes to the acquisition of the necessary criteria by the students to evaluate and correct their own answers. When comparing our results, we see that the teacher's control mode in both investigated contexts differs significantly. In the public school, his most frequently used control mode to face the students' questions was imperative/positional while he used mostly personal control in the private school.

To verify the relations between the communication control exercised by the teacher and the types of elicitation presented by the students, we analyzed the trend of the framing degree for each elicitation type found in the two schools. Our goal was to verify if the different types of elicitation were associated with varying degrees of control, with weaker framings producing different chains of interaction and questions with a higher conceptual level. The results of this analysis shows that process and metaprocess elicitations were more produced in weaker framing degrees, as shown in Figures 20 and 21.

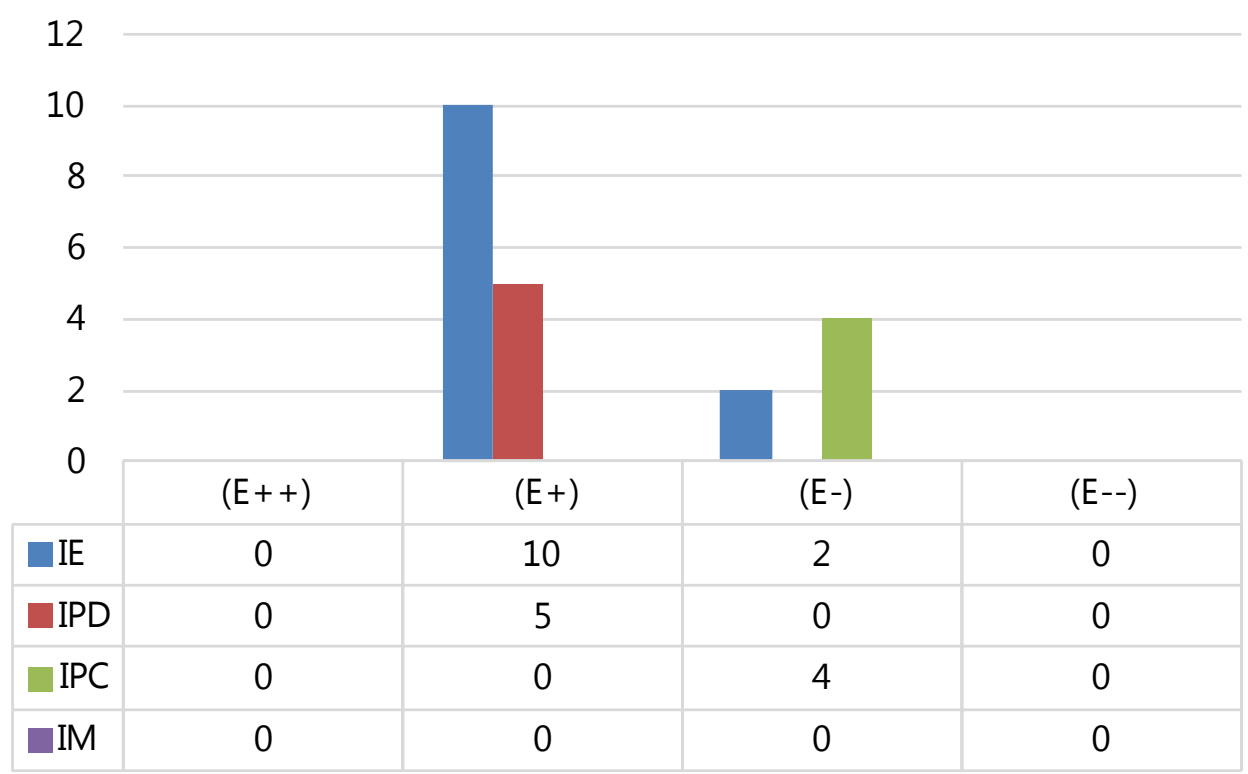

Figure 20. Relationship between the teacher's framing degree and the elicitation types of the public schools students

Source: Own elaboration 


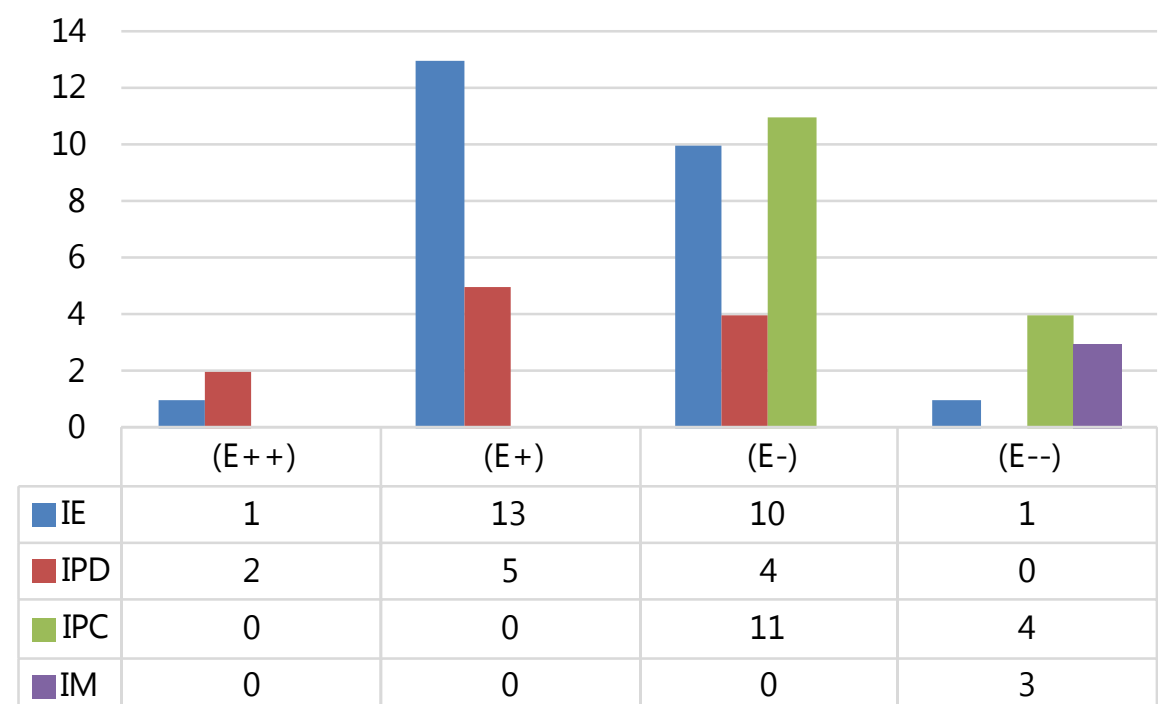

Figure 21. Relationship between the teacher's framing degree and the elicitation types of the private schools students

Source: Own elaboration

The results of this analysis show an association between process and metaprocess elicitation in both schools with the degrees of weak and very weak framing. This means that the questions that elicit opinions and interpretations from the teacher, i.e. those of greater conceptual demand, generated more prolonged interaction chains, which enriched the classroom dialogue. However, in the private school, several episodes with product elicitations, or even choice elicitations, produced, with greater frequency, weak and very weak framing degrees, when compared with the results of the public school. Figure 22 shows two examples of episodes with weak framing $\left(\mathrm{E}^{-}\right)$for both schools.

\begin{tabular}{|l|l|}
\hline PU: Lesson on chemical reactions & PR: Lesson on Molecular Geometry \\
\hline & $\begin{array}{l}\text { Student 2: Teacher, wait there. Isn't that wrong? } \\
\text { (Process elicitation) }\end{array}$ \\
Teacher: Which is the radical? Isn't the radical & (Choice Initiation) \\
sulf, isn't the termination ico? From ico it & Teacher: Erm, ok... it is a cation, right? It means \\
changes to ato. & Student: Eight. \\
Student: Magnesium is from the base, right? & Teacher: Eight divided by two. \\
Teacher: And magnesium is from the base. & Student: Four. \\
Then you repeat the name. Then, there is & Teacher: Right... if it were an anion it would be \\
magnesium sulfate left. Let's practice. & nine plus one, if it were a divalent cation it would \\
(E-) & be nine minus two and so on. \\
& (E-) \\
\hline
\end{tabular}

Source: Own elaboration

Figure 22. fragments of the episodes of the PU and PR students' questions 
In the fragment of the private school, a simpler conceptual demand elicitation originated the same positioning observed for a process elicitation in the public school.

The differences found with respect to the students' questions in both schools and the teacher's positioning regarding the pedagogic control were more pronounced than those observed for the teacher's questions and his positioning regarding the students' responses. Again, the pacing of the pedagogic practice helps to understand these differences, since, according to Bernstein (1988), a strong pacing favors a lexical pedagogic code, in which single worded answers or short sentences expressing facts or skills or individual operations are more typical of schools with students from disadvantaged social classes, while a syntactic pedagogic code, expressing relationships, processes and connections can be more typical of schools with middle-class students, although this author also notes that even in this type of school the students' participation may be restricted.

We also believe that the communicative practices of the families and communities in which these students are inserted originate from different social hierarchies, with varying degrees of classification among them, especially in the relationship between parents and/or guardians and children. As the control exercised by the teacher regulates the extent to which skills and communicative practices of families and communities can be effective in the classroom discourse (Bernstein, 1988), the contributions of the students in interactions put the teacher in a different position in the two schools where he teaches. His tendency to a more imperative control in the public school results in a more passive behavior of the students. In the private school, a more personal control, based on less asymmetrical relations between the teacher and his students, produced a higher participation of his students.

\section{Final remarks}

In this article, we analyzed the questions of a chemistry teacher and his students in high school classes in two schools with different socioeconomic profiles. The questions were analyzed in two dimensions: an epistemic one, through elicitation types, which provided us with a classification of questions related to the conceptual demand of disciplinary knowledge; and an interactional one, which allowed us to evaluate the positioning of the teacher facing these questions and answers, through framing degrees in the pedagogic discourse. The most significant differences in our analysis are related to the amount of questions and the types of questions from the students, and the teacher's positioning regarding those questions.

Overall, the discursive interactions involving questions were more numerous and involved more elicitation types in the private school. The teacher's positioning with respect to his own questions varied slightly between the schools, being somewhat more favorable in the public school if we consider his tendency to a weaker framing in relation to the private school. This can be explained as an effect of a greater difficulty of the students in learning the names of concepts and implementing numerical calculations, 
which led the professor to extend the interactions with new questions when he was faced with these difficulties. Still, with respect to the students' questions, his positioning varied more sharply between schools, with weaker framing degrees when facing the questions in the private school. This positioning produced interaction patterns that distanced themselves from the typical IRE pattern, especially when the elicitations had a greater conceptual demand.

According to the sociocultural perspective, discursive interactions play a key role in the learning of Sciences in the classroom. The fact that these interactions are more promoted with students from a more favored social context shows us the influence of this context and its manifestation on communicative practices in pedagogic relations. Our results, however, do not signal any kind of deficit or cognitive difference between the students of this teacher, but different cultural ways of participation and involvement in the classroom dialogue. We neither suggest that, deliberately and consciously, this teacher establishes unequal practices among these students. On this point, we agree with Morais and Miranda who argue that:

Schools placed in different cultural and socioeconomic contexts reproduce differentiated organizational structures and forms of communication which are reflected in the classroom (Morais, \& Miranda, 1996, p. 602).

In this case, the different pacing of his pedagogic practice in the two schools, which we attribute to the number of classes available per week, is reflected in the quality of the questions produced during the discursive interactions.

Regarding the theoretical and methodological framework used in this study, we consider that the juxtaposition of Basil Bernstein's pedagogic discourse theory and Hugh Mehan's typology enabled an analysis of the internal logic - i.e. the regulative principles - of pedagogic transmission and its relationship with what is transmitted (Bernstein, 1988). In the analysis presented in this paper, we only used the concept of framing for the study of classroom discourse, although we are aware that, as stated by Straehler-Pool and Gellert,

It is the analysis of the interplay of classification and framing that allows us to detect the interactive mechanisms that promote the reproduction of inequalities on the classroom level (Straehler-Pool, \& Gellert, 2013, p. 329).

The absence of the classification analysis remains a gap in our study, which we intend to fill with other work, as we still lack the tools for this task.

Finally, we draw attention to the fact that Science teachers training should deepen the issues associated with classroom discourse and with the development of pedagogic practices more favorable to the interactions between teachers and students in order to incorporate stimulus strategies to dialogues promoting the acquisition of scientific language and concepts by the learners, considering their totality in the classroom and not just a few students. 


\section{Acknowledgments}

To CNPq, the Fapesb and the Capes.

\section{References}

Aguiar Jr. O. G., Mortimer, E. F., \& Scott, P. H. (2006). As perguntas dos estudantes e seus desdobramentos no discurso da sala de aula de ciências. In Resumos do X Encontro de Pesquisa em Ensino de Física. Londrina, PR.

Aguiar Jr., O. G., Mendonça, D. H., \& Silva, N.S. (2007). Análise do discurso em uma sala de aula de Ciências: a postura do professor e a participação dos estudantes. In Anais do VI Encontro Nacional de Pesquisa em Educação em Ciências. Florianópolis, SC.

Altet, M. (2000). Análise das práticas dos professores e das situações pedagógicas. Porto: Porto Editora.

Andrade, G. M. P. C., \& Mozzer, N. B. (2016). Análise dos questionamentos do professor em atividades fundamentadas em modelagem analógica. Revista Brasileira de Pesquisa em Educação em Ciências, 16(3), 825-850.

Bachelard, G. (1996). A formação do espírito científico. Rio de Janeiro: Contraponto.

Bernstein, B. (1988). Poder, educación y conciencia. Sociología de la transmisión cultural. Santiago: CIDE.

Bernstein, B. (2001). La estructura del discurso pedagógico, 4ª ed. Madrid: Morata.

Bleicher, R. E., Tobin, K. G., \& McRobbie, C. J. (2003). Opportunities to talk Science in a high school chemistry classroom. Research in Science Education, 33(3), 319-339. https:// doi.org/10.1023\%2FA\%3A1025480311414

Chin, C. (2006). Classroom interaction in Science: teacher questioning and feedback to students' responses. International Journal of Science Education, 28(11), 1315-1346. https://doi.org/10.1080/09500690600621100

Erdogan, I., \& Campbell, T. (2008). Teacher questioning and interaction patterns in classrooms facilitated with different levels of constructivist teaching practices. International Journal of Science Education, 30(14), 1891-1914. https://doi. org/10.1080/09500690701587028

Jackson, P. W. (2002). Prácticas de la enseñanza. Buenos Aires: Amorrortu.

Kawalkar, A., \& Vijapurkar, J. Scaffolding science talk: the role of teachers' questions in the inquiry classroom. International Journal of Science Education, 35(12), 2004-2027. https://doi.org/10.1080/09500693.2011.604684

Lee, O. (2005). Science education with English language learners: synthesis and research agenda. Review of Educational Research, 75(4), 491-530. https://doi. org/10.3102/00346543075004491 
Lemke, J. (1997). Aprender a hablar ciencia: lenguaje, aprendizaje y valores. Barcelona: Paidós.

Magalhães, S. C., Mortimer, E. F. \& Silva, A. F. (2016). Uma análise da relação entre a abordagem comunicativa e os tipos de perguntas de duas professoras da Educação Básica nas aulas de termoquímica. In Anais do XVIII Encontro Nacional de Ensino de Química. Florianópolis, SC.

Mehan, H. (1979). Learning lessons. Social organization in the classroom. Cambridge: Harvard University Press.

Moore, R., \& Muller, J. (2003). O crescimento do conhecimento e a lacuna discursiva. Educação \& Sociedade, 24(85), 1343-1360.

Morais, A. M. (2002). Basil Bernstein at the microlevel of classroom. British Journal of Sociology of Education, 23(4), 559-569.

Morais, A. M., \& Miranda, C. (1996). Understanding teachers' evaluation criteria: a condition for success in Science classes. Journal of Research in Science Teaching. 33(6), 601-624.

Morais, A. M., \& Neves, I. P. (2001). Pedagogic social contexts: studies for a sociology of learning. In A. M. Morais, I. Neves, B. Davies, \& H. Daniels (Eds.). Towards a sociology of pedagogy: the contribution of Basil Bernstein to research (pp. 185-221). New York: Peter Lang.

Mortimer, E. F., Massicame, T., Buty, C., \& Tiberghien, A. (2007). Uma metodologia para caracterizar os gêneros de discurso como tipos de estratégias enunciativas nas aulas de ciências. In R., Nardi, A pesquisa em ensino de Ciência no Brasil: alguns recortes (pp. 53-94). São Paulo, SP: Escrituras.

Neiman, G., \& Quaranta, G. (2007). Los estudios de caso en la investigación sociológica. In I.V., Gialdino, (Coord.), Estrategias de investigación cualitativa (pp. 213-235). Buenos Aires: Gedisa.

Quílez-Pardo, J. (2016). El lenguaje de la ciencia como obstáculo de aprendizaje de los conocimientos científicos y propuestas para superarlo. Revista Brasileira de Pesquisa em Educação em Ciências, 16(2), 449-476.

Silva, C. P. (2015). Interações discursivas em aulas de Química: relações com o engajamento dos alunos. (Dissertação de Mestrado em Ensino de Ciências e Matemática). Universidade Federal de Sergipe, Aracaju.

Schein, Z. P., \& Coelho, S. M. (2006). O papel do questionamento: intervenções do professor e do aluno na construção do conhecimento. Caderno Brasileiro de Ensino de Física, 23(1), 68-92. 
Specht, C. C., Ribeiro, M. E. M., \& Ramos, M. G. (2017). Estudo das perguntas de professores e estudantes em aulas de Química. Revista Thema, 14, 225-242. http:// dx.doi.org/10.15536/thema.14.2017.225-242.395

Souza, G. M. (2015). A influência do contexto social sobre a prática pedagógica de Química: uma análise na perspectiva de Basil Bernstein. (Dissertação de Mestrado em Educação Científica e Formação de Professores de Ciências e Matemática). Universidade Estadual do Sudoeste da Bahia, Jequié.

Straehler-Pool, H., Gellert, U. (2013). Towards a Bernsteinian language of description for mathematics classroom discourse. British Journal of Sociology of Education, 34(3), 313-332.

Tobin, K. (1987). The role of waiting time in higher cognitive level learning. Review of Educational Research, 57(1), 69-95. https://doi.org/10.3102/00346543057001069

Torres, J., Almeida, A., \& Vasconcelos, C. (2015). Questionamentos em manuais escolares: um estudo no âmbito das Ciências Naturais. Ciência \& Educação, 21(3), 655671. https://doi.org/10.1590/1516-731320150030009

Tytler, R., Aranda, G. (2015). Expert teachers' discursive moves in Science classroom interactive talk. International Journal of Science and Mathematics Education, 3(2), 425446.

van Zee, E., \& Minstrell, J. (1997). Using questioning to guide student thinking. Journal of the Learning Sciences, 6(2), 227-269. https://doi.org/10.1207/s15327809jls0602_3

Yin, R.K. (2005). Estudo de caso: planejamento e métodos, $3^{\mathrm{a}}$ ed.. Porto Alegre: Bookman. 
Rivaldo Lopes da Silva

() http://orcid.org/0000-0002-8587-457X

Universidade Estadual do Sudoeste da Bahia Programa de Pós Graduação em Educação Científica e Formação de

Professores de Ciências e Matemática Jequié, Brazil rivaldo.lopesdasilva31@gmail.com

Geovânia Moreira Souza

(1) http://orcid.org/0000-0002-2263-7710

Universidade Estadual do Sudoeste da Bahia Programa de Pós Graduação em Educação Científica e Formação de Professores de Ciências e Matemática Jequié, Brazil geovania.quimica@hotmail.com

\section{Bruno Ferreira dos Santos}

(ํ) https://orcid.org/0000-0002-6168-2303 Universidade Estadual do Sudoeste da Bahia

Departamento de Ciências e Tecnologias Jequié, Brazil bf-santos@uol.com.br

Submitted on 5th February 2018

Accepted on 21st February 2018

Published on 24th April 2018 